\title{
Validation of in situ hybridisation and histology assays for the detection of the oyster parasite Marteilia refringens
}

\author{
A. Thébault ${ }^{1}$, S. Bergman ${ }^{2}$, R. Pouillot ${ }^{1}$, F. Le Roux ${ }^{3}$, F. C. J. Berthe ${ }^{4, *}$ \\ ${ }^{1}$ Agence Française de Sécurité Sanitaire des Aliments - La Direction de l'Évaluation des Risques Nutritionnels et \\ Sanitares (AFSSA-DERNS), Unité d'Appui Epidémiologique à l'Analyse du Risque, 27-31 Avenue du Général Leclerc, \\ BP 19, 94701 Maisons-Alfort, France \\ ${ }^{2}$ Federal Research Centre for Virus Diseases of Animals, National Reference Laboratory for Mussel Diseases, \\ Boddenblick 5 a, 17498 Insel Riems, Germany \\ ${ }^{3}$ IFREMER, Laboratoire de Génétique et Pathologie, Community Reference Laboratory for Mollusc Diseases, \\ Reference Laboratory for Bonamiosis and Marteiliosis, BP 133, 17390 La Tremblade, France \\ ${ }^{4}$ Department of Pathology \& Microbiology, Atlantic Veterinary College, University of Prince Edward Island, \\ 550 University Ave., Charlottetown, Prince Edward Island C1A 4P3, Canada
}

\begin{abstract}
An in situ hybridisation technique has been developed for the detection of infection in oysters with Marteilia refringens with particular emphasis on light infections or confirmation of suspected cases by means of histology. Although validation of new diagnostic methods is usually achieved by comparison with standard techniques, in our case the sensitivity and specificity of the standard (histology) had not previously been established. Another point to consider is that surveillance and monitoring frequently target populations displaying different levels of prevalence under different field conditions. The objective of our study was to evaluate the sensitivity and specificity values of in situ hybridisation and histology for the detection of $M$. refringens, based on 3 populations of flat oysters, free of the disease and with mild and high levels of prevalence. A blind assay of 200 individuals from each population was performed using both techniques. Results were analysed by means of the classical approach and latent models (maximum likehood and Bayesian approach). Assumptions and results were found to vary slightly with the different statistical approaches. The more realistic estimate by the Bayesian approach shows a link between the level of prevalence and the sensitivity of the techniques. Values of sensitivity and specificity for histology were 0.7 and 0.99 respectively, and 0.9 and 0.99 respectively in the case of in situ hybridisation. Some uncertainty remains regarding these values because the study does not take into account the severity of infection or the developmental stages of the parasite actually present in each individual. This work provides valuable information with regard to the choice and potential use of those 2 diagnostic methods currently recommended by international standards.
\end{abstract}

KEY WORDS: Diagnostic $\cdot$ Validation $\cdot$ Sensitivity $\cdot$ Specificity $\cdot$ Latent models $\cdot$ Marteilia refringens $\cdot$ Ostrea edulis

\section{INTRODUCTION}

Marteilia refringens is a paramyxean parasite of the European flat oyster Ostrea edulis (Grizel et al. 1974, Berthe et al. 2000). It has been a cause of mass mortality in Europe (Grizel 1985), and continues to strongly impede the production of flat oysters. The geographical distribution of the disease ranges from a northern limit in western Brittany on the French Atlantic coast to a southern limit identified as being the Mediterranean Sea (Audemard et al. 2002). In Australia, Marteilia sydneyi is responsible for QX 
disease in the Sydney rock oyster Saccostrea (commercialis) glomearata (Perkins \& Wolf 1976). M. refringens and $M$. sydneyi are currently recognised as significant pathogens of molluscs by the Office International des Epizootes, the World Organisation for Animal Health (OIE 2003a).

Techniques applicable to the diagnosis of pathogens of molluscs have historically been based on histological and ultrastructural examinations. The accuracy of diagnosis by means of these 'eye based' methods is strongly linked to the experience of the investigator and the time allocated to the examination. Many molluscan pathogens are difficult to detect and recognise, particularly when present in low numbers or when in the early stages of development (Berthe et al. 1999). During its development, Marteilia refringens undergoes continuous enlargement of the primary cell cytoplasm and, within this, the number of daughter cells increases by serial endogenous division. Although the size of $M$. refringens cells ranges from 7 to $35 \mu \mathrm{m}$ (Grizel 1985), young stages, usually observed in the epithelia of the upper digestive tract and in the gills, can be difficult to detect. In addition, specificity of histological diagnosis relies on strong assumptions in geographic and host distribution of pathogens. Another species of the genus, Marteilia maurini, was described in mussels Mytilus galloprovincialis (Comps et al. 1982) and later validated by sequencing of the rRNA gene cluster (Berthe et al. 2000, Le Roux et al. 2001, Zrncic et al. 2001). However, diagnosis of the 2 Marteilia species remains difficult since ultrastructural characteristics and host specificity were rejected as valid criteria (Longshaw et al. 2001, Le Roux et al. 2001).

In situ hybridisation was initially developed and used as a tool for scientific investigation in order to elucidate the life cycle of Marteilia refringens and localise the parasite in tissues of potential intermediate hosts after PCR detection (Berthe et al. 1998, Le Roux et al. 1999, Audemard et al. 2001, 2002). However, in situ hybridisation also has potential in diagnostic laboratories. In this respect, in situ hybridisation is regarded as a way to overcome diagnosis difficulties and is a useful improvement in the detection of light infections and confirmation of the pathogen affiliation.

DNA-based methods are increasingly seen as valuable and reliable diagnostic methods, although their sensitivity and specificity need to be compared to the standard methods. Problems arise when the new diagnostic test is assumed to be more sensitive and specific than previous standards, despite existing false positive or false negative results (Berthe et al. 1999). Also, evaluation of new tests is often performed in only one population with the assumption of stable values for specificity and sensitivity when they may vary under different prevalence and field conditions (Walker \& Subasinghe 2000).

Preliminary studies on the specificity of in situ hybridisation under consideration and on possible cross reactions were earlier published (Le Roux et al. 1999, Kleeman et al. 2002). The purpose of this study was to evaluate, by different methodological approaches, the sensitivity and specificity of in situ hybridisation and histology assays when applied to the detection of Marteilia refringens, in 3 different populations of Ostrea edulis and under varying prevalence and field conditions.

\section{MATERIALS AND METHODS}

Origin of oysters included in the study. Samples of 200 flat oysters, Ostrea edulis, were collected from areas naturally infected with Marteilia refringens, namely Brittany (France) and Marennes Oléron (France), and from a known disease-free zone in The Netherlands. Sampling was performed during the summer period when the parasite undergoes sporulation.

Histology and in situ hybridisation procedures. For histology (HIST), sections were cut through soft tissues, including the visceral mass, and placed in Davidson's fixative AFA (10\% glycerine, $20 \%$ formalin, $30 \%$ $95^{\circ}$ ethanol, $30 \% \mathrm{H}_{2} \mathrm{O}, 10 \%$ glacial acetic acid) for $24 \mathrm{~h}$ and then treated following standard procedures recommended in the OIE Manual for diagnostic procedures of aquatic animal diseases (OIE 2003b). Sections were cut $2 \mu \mathrm{m}$ thick and stained with hematoxylin and eosin (H\&E). For in situ hybridisation (ISH), $5 \mu \mathrm{m}$ thick sections were cut and placed on aminoalkylsilane coated slides (Silane-Prep Slides, Sigma) and then baked overnight in an oven at $60^{\circ} \mathrm{C}$. Sections were subsequently treated according to the previously published procedure (Le Roux et al. 1999).

Examination methodology. A reference number was given for identification of each slide. In the course of the study, the 600 slides were randomly mixed and analysed by means of both histology and in situ hybridisation under a random ID number, in order to perform blind examinations and avoid bias of readers expected results.

Statistical analysis. Three different approaches were conducted during the study. In a classic approach, histology was considered as the reference method ('gold standard') where sensitivity and specificity were assumed to be unity. Estimates of sensitivity and specificity of in situ hybridisation were performed for each individual in a bulk of samples and compared to histological examination.

A second means of data analysis was based on the maximum likelihood method (Newton Raphson and Expectation Maximisation algorithms) using the TAGS 
V.2.0 programme as previously described (Pouillot et al. 2002). The algorithm uses 2 strong assumptions: (1) test results are considered as conditionally independent and (2) test diagnostic values are considered as constant when applied to different populations. The analysis was performed separately for the 3 populations of oysters included in the study. The reference population was chosen as the one from The Netherlands, as being an assumed disease-free population.

The third way to analyse the data was an iterative Markov Chain Monte Carlo (MCMC) technique, using the Gibbs sampler to approximate the marginal posterior densities of the parameters of interest (identified as being sensitivity, specificity and prevalence) in the absence of a gold standard. A programme developed in WinBUGS $^{\odot}$ software (Imperial College and Medical Research Council) (Spiegelhalter et al. 1996) version 1.3 was used. Three different scenarios were applied with specific prior distributions. One common assumption among the 3 models was that all individuals from The Netherlands were free of Marteilia refringens. This provided the foundation basis or prior distribution for specificity of in situ hybridisation and histology assays.

Model 1: For each sample from Brittany and Marennes, prior distribution of prevalence and sensitivity of in situ hybridisation and histology showed a uniform distribution, ranging between 0 and 1 . In this scenario, no information was available on what those values could be (uninformative prior distribution). Results between diagnosis techniques were independent, taking into account the global result in each population. Sensitivity and specificity were assumed to be constant between different samples. The number of positive results for each population was estimated by a binomial distribution.

Model 2: The probability of infection and detection of positives by in situ hybridisation or histology was considered for each individual. Sensitivity and specificity were assumed to be constant between different samples. The results between techniques were not completely independent, considering that an individual yielding a positive result for the 2 tests was more likely to be really infected.

Model 3: This model is similar to the previous one except that the sensitivity and specificity were not assumed to be constant among samples.
The initial values were generated by WinBUGS. Two separate chains starting from different values were run for each model. Convergence was checked by visual examination of 'trace' or 'time series' plots of the samples for each chain and by computing the Gelman-Rubin statistics as modified by Brooks \& Gelman (1998), comparing the pooled and within interval widths of each parameter. On this basis, the first 40000 samples of each iteration were discarded as 'burn-in'; each chain was run for a further 20000 iterations, and posterior estimates were based on the pooling of $2 \times 20000$ samples for the first model. For the second and third models 20000 for burn-in, and $2 \times 20000$ samples for posterior estimates were used. It was validated so that for each parameter, the Monte Carlo error is less than $5 \%$ of sample (posterior) standard deviation.

\section{RESULTS}

The results of the classical method of analysis are shown in Tables 1 \& 2 . The results of in situ hybridisation show that the sensitivity was high, with an average value of 0.95 . The value of specificity was differ-

Table 1. Classical estimation of sensitivity (Se) and specificity (Sp) of in situ hybridisation (ISH) based on results obtained in Brittany. Se ISH $=25 /(25+3)=$ $0.89,95 \%$ confidence interval $(\mathrm{CI})=0.889-0.891$. SP ISH $=161 /(161+11)=$ $0.936,95 \% \mathrm{CI}=0.935-0.937$

\begin{tabular}{|cccc|}
\hline & $\begin{array}{c}\text { Positive by } \\
\text { histological } \\
\text { examination } \\
\text { infected }\end{array}$ & $\begin{array}{c}\text { Negative by } \\
\text { histological } \\
\text { examination }= \\
\text { not infected }\end{array}$ & Total \\
\hline $\begin{array}{c}\text { Positive by in situ } \\
\text { hybridisation (ISH) }\end{array}$ & 25 & 11 & 33 \\
$\begin{array}{c}\text { Negative by in situ } \\
\text { hybridisation (ISH) }\end{array}$ & 3 & 161 & 164 \\
\hline
\end{tabular}

Table 2. Classical estimation of sensitivity (Se) and specificity (Sp) of in situ hybridisation (ISH) based on results obtained in Marennes Oléron. SE ISH = $119 /(119+4)=0.97,95 \%$ confidence interval $(\mathrm{CI})=0.969-0.971$. Sp ISH $=$ $30 /(30+45)=0.4,95 \% \mathrm{CI}=0.397-0.402$

\begin{tabular}{|cccc|}
\hline & $\begin{array}{c}\text { Positive by } \\
\text { histological } \\
\text { examination } \\
\text { infected }\end{array}$ & $\begin{array}{c}\text { Negative by } \\
\text { histological } \\
\text { examination }= \\
\text { not infected }\end{array}$ & Total \\
\hline $\begin{array}{c}\text { Positive by in situ } \\
\text { hybridisation (ISH) }\end{array}$ & 119 & 45 & 164 \\
$\begin{array}{c}\text { Negative by in situ } \\
\text { hybridisation (ISH) }\end{array}$ & 4 & 30 & 34 \\
\hline
\end{tabular}


ent, decreasing between the population of high prevalence (0.93) and the population of low prevalence (0.4), with an average of 0.77 .

The results from The Netherlands samples are important because no positive oyster was detected for both diagnostic tools. In this case specificity of ISH was 1 (Table 3).

The results of sensitivity and specificity of ISH and HIST by maximum likelihood are shown in Table 4. The value of specificity for the 2 diagnostic procedures was extremely high, being nearly 1 . The value of sensitivity was higher for ISH (about 0.95) than for HIST (0.72). The results did not differ significantly between populations of high and low prevalence. The analysis of correlation between the diagnostic test was not significant (results not shown).

The results of estimation for sensitivity and specificity by means of Bayesian analysis are shown in Tables 5,6 \& 7. The assumptions between these 3 tables are different: the estimation of sensitivity of ISH was around 0.9 and for HIST around 0.7 (Tables 5 \& 6). The estimation of specificity was around 0.99 for both diagnostic tools (Tables 5 and 6).

Table 7 shows some differences in sensitivity of methods between the populations of high and low prevalence, decreasing with the level of prevalence. The sensitivity of ISH was still more elevated than for HIST for both populations.

Table 3. Classical estimation of sensitivity (Se) and specificity (Sp) of in situ hybridisation (ISH) based on results obtained in The Netherlands. Se ISH could not be estimated, $\mathrm{Sp} \mathrm{ISH}=1$

\begin{tabular}{|cccc|}
\hline & $\begin{array}{c}\text { Positive by } \\
\text { histological } \\
\text { examination } \\
\text { infected }\end{array}$ & $\begin{array}{c}\text { Negative by } \\
\text { histological } \\
\text { examination }= \\
\text { not infected }\end{array}$ & Total \\
\hline $\begin{array}{c}\text { Positive by in situ } \\
\text { hybridisation (ISH) }\end{array}$ & 0 & 0 & 0 \\
$\begin{array}{c}\text { Negative by in situ } \\
\text { hybridisation (ISH) }\end{array}$ & 0 & 200 & 200 \\
\hline
\end{tabular}

Table 4. Maximum likelihood estimation of sensitivity (Se) and specificity (Sp) of histological examination (HIST) and in situ hybridisation (ISH) by expectation maximisation for Brittany (low prevalence) and Marennes (high prevalence). NA: not available

\begin{tabular}{|lccc|}
\hline & Brittany & Marennes & All populations \\
\hline Se ISH & $0.89(0.71-0.96)$ & $0.96(0.92-0.99)$ & 0.95 (NA) \\
Se HIST & $0.70(0.53-0.82)$ & $0.72(0.65-0.79)$ & $0.72(\mathrm{NA})$ \\
Sp ISH & 1 (NA) & 1 (NA) & 1 (NA) \\
Sp HIST & 1 (NA) & 1 (NA) & 1 (NA) \\
Prevalence & $0.20(0.15-0.26)$ & $0.85(0.80-0.9)$ & \\
\hline
\end{tabular}

Results shown in Table 8 compare results between the 3 methods of evaluation of sensitivity and specificity.

\section{DISCUSSION}

It is now widely recognised that the effective control of infectious diseases of molluscs requires access to diagnostic tests and procedures that are rapid, reliable, specific and sensitive (Berthe et al. 1999). Traditionally, techniques applicable to pathogens of molluscs are limited and consist primarily of histology and transmission electron microscopy. Many pathogens are difficult to detect using these methods. Also, a major constraint of these techniques lies in the time required by diagnostic laboratories. As an answer to this, a number of research teams have recently been engaged in developing DNA-based diagnostic techniques for mollusc pathogens. In situ hybridisation can solve difficulties linked to specificity as long as the taxonomy of targeted organisms has been clearly established. This technique has been moving rapidly from development in research to routine application in diagnostic laboratories and could be adopted as an international standard in the next few years. Over the past decade, efforts were made to overcome constraints and difficulties met by diagnosticians; this led to the development of nucleic acid based diagnostic methods for major pathogens of molluscs (Stokes \& Burreson 1995, Le Roux et al. 1999, Cochennec et al. 2000). The use of gene probes is based on the fact that every species carries unique DNA sequences that can be targeted and used to differentiate any given species from other organisms. In situ hybridisation offers the theoretical advantages of high specificity, increased sensitivity and possible rapid screening of aquatic organisms for the presence of a given pathogen. While recognising the difficulties and limitations of histology and related techniques, one should also emphasise that the routine use of in situ hybridisation is hampered by a number of problems. The extremely high specificity of the technique can result in a failure to detect strains or types that have key modifications in the targeted sequence for probe design. False negatives are also easily caused by the selection of inappropriate host tissue sources for detection of the pathogen in question, by inappropriate tissue fixation procedures or by inhibitory factors. 
Table 5. Bayesian method of estimation of sensitivity (Se) and specificity (Sp) of histology (HIST) and in situ hybridisation (ISH) assays with assumption of constant values of sensitivity and specificity (Model 1) and independence between tests results conditional on the health status of the individual. $\mathrm{CI}=$ confidence interval

\begin{tabular}{|lcccccc|}
\hline & Mean & SD & Median & $2.5 \%$ CI & $97.5 \%$ CI & $\begin{array}{c}\text { Monte Carlo } \\
\text { Error }\end{array}$ \\
\hline Se ISH & 0.91 & 0.05 & 0.91 & 0.80 & 0.995 & 0.000533 \\
Se HIST & 0.69 & 0.05 & 0.68 & 0.59 & 0.80 & 0.00046 \\
Sp ISH & 0.995 & 0.005 & 0.996 & 0.982 & 0.99 & 0.000024 \\
Sp HIST & 0.995 & 0.004 & 0.996 & 0.98 & 0.99 & 0.000024 \\
$\begin{array}{l}\text { Prevalence } \\
\text { Marennes }\end{array}$ & 0.91 & 0.055 & 0.91 & 0.80 & 0.99 & 0.00054 \\
Brittany & 0.20 & 0.05 & 0.197 & 0.15 & 0.25 & 0.00053 \\
Netherlands & 0 & 0 & 0 & & & \\
\hline
\end{tabular}

Table 6. Bayesian method of estimation of sensitivity (Se) and specificity (Sp) of histology (HIST) and in situ hybridisation (ISH) assays, assuming that sensitivity and specificity values are constant (Model 2) and results test can be correlated. $\mathrm{CI}=$ confidence interval

\begin{tabular}{|lcccccc|}
\hline & Mean & SD & Median & $2.5 \%$ CI & $97.5 \%$ CI & $\begin{array}{c}\text { Monte Carlo } \\
\text { Error }\end{array}$ \\
\hline Se ISH & 0.95 & 0.02 & 0.96 & 0.91 & 0.99 & 0.00016 \\
Se HIST & 0.72 & 0.03 & 0.72 & 0.65 & 0.78 & 0.00018 \\
Sp ISH & 0.995 & 0.005 & 0.996 & 0.982 & 0.99 & 0.00005 \\
Sp HIST & 0.995 & 0.004 & 0.995 & 0.98 & 0.99 & 0.000044 \\
Prevalence & & & & & & 0.9 \\
$\quad$ Marennes & 0.85 & 0.03 & 0.855 & 0.8 & 0.9 & 0.00017 \\
Brittany & 0.19 & 0.028 & 0.189 & 0.14 & 0.25 & 0.00018 \\
Netherlands & 0 & 0 & 0 & 0 & & \\
\hline
\end{tabular}

Table 7. Bayesian method of estimation of sensitivity (Se) and specificity (Sp) of histology (HIST) and in situ hybridisation (ISH) assays assuming that sensitivity and specificity values are not constant between samples (Model 3). Confidence interval ranges are in parentheses

\begin{tabular}{|lcc|}
\hline & $\begin{array}{c}\text { Marennes } \\
\text { (high prevalence) }\end{array}$ & $\begin{array}{c}\text { Brittany } \\
\text { (low prevalence) }\end{array}$ \\
\hline Se ISH & $0.96(0.92-0.99)$ & $0.88(0.74-0.99)$ \\
Se HIST & $0.72(0.65-0.78)$ & $0.69(0.53-0.843)$ \\
Sp ISH & $0.995(0.98-0.999)$ & $0.995(0.98-0.999)$ \\
Sp HIST & $0.995(0.98-0.999)$ & $0.995(0.98-0.999)$ \\
Prevalence & 0.85 & 0.2 \\
\hline
\end{tabular}

Given the potential for widespread application of the technique and the inherent problems currently associated with its use, it appears necessary to address the issue of validation.

Although histology is proposed and accepted as the standard, it has never been validated. In order to measure test agreement, sensitivity and specificity of the compared assays were estimated in this study by maximum likelihood or Bayesian methods, assuming that none of these is the 'gold standard'. Such models are referred to as latent class models since the true classification of the individuals is unknown. The maximum likelihood methods were previously developed (Hui \& Walter 1980, Chriel et al. 1997, Enoe et al. 2000, Pouillot et al. 2002) and likelihood equations were solved by Newton Raphson or Expectation Maximisation algorithms. The algorithms make 2 important assumptions: (1) test results are considered conditionally independent and (2) test diagnostic values are considered constant when applied to different populations.

A different approach is the Bayesian method using the Gibbs sampler, which allows the uncertainty of the true value of all the parameters of interest to vary (Joseph et al. 1995). This also permits the estimation of sensitivity and specificity without a reference test and evaluates the assumption of independence between prevalence and test characteristics (Chriel \& Willeberg 1997). The Gibbs sampler is an iterative Markov Chain Monte Carlo technique. Using the specified prior distribution for sensitivity, specificity and prevalence (typically beta priors), the Gibbs sampler provides a distribution of prevalence and test performance values (posterior densities). From these distributions, median sensitivities and specificities and associated 95\% credible intervals (the Bayesian analogue of confidence intervals) can be calculated (Chriel \& Willeberg 1997, Pouillot \& Gerbier 2000).

Results obtained show the capacity to estimate sensitivity and specificity without a gold standard. Mainly, values of sensitivity and specificity of histology can be estimated. These values can then be used for designing the sampling schemes of monitoring programmes (Thébault et al. 2001). The sensitivity value of histology (HIST), as a diagnostic assay for the detection of Marteilia refringens, is around 0.7 and its specificity around 0.99 (Table 7). Results for in situ hybridisation (ISH) show higher values of sensitivities (between 0.96 and 0.88 using the MCMC method) than for histology (Table 7). Interestingly, values of specificity appear equivalent to those obtained for histology. If only the classical method had been applied, the specificity of in situ hybridisation would have been artificially underestimated. This is a key point raised by this study when comparing different approaches of estimation. 
Table 8. Comparison of estimation of sensitivity (Se) and specificity (Sp) of histology (HIST) and in situ hybridisation (ISH) assays by different statistical approaches. Prev: prevalence; MCMC: Markov Chain Monte Carlo; ML: maximum likelihood; ${ }^{*}$ : could not be estimated

\begin{tabular}{|c|c|c|c|c|c|c|c|c|c|c|}
\hline & \multicolumn{5}{|c|}{-Marennes } & \multicolumn{5}{|c|}{ - Brittany - } \\
\hline & $\begin{array}{l}\mathrm{Se} \\
\text { ISH }\end{array}$ & $\begin{array}{c}\text { Se } \\
\text { HIST }\end{array}$ & $\begin{array}{l}\mathrm{Sp} \\
\text { ISH }\end{array}$ & $\begin{array}{c}\text { Sp } \\
\text { HIST }\end{array}$ & Prev. & $\begin{array}{l}\mathrm{Se} \\
\text { ISH }\end{array}$ & $\begin{array}{c}\mathrm{Se} \\
\mathrm{HIST}\end{array}$ & $\begin{array}{l}\text { Sp } \\
\text { ISH }\end{array}$ & $\begin{array}{l}\text { Sp } \\
\text { HIST }\end{array}$ & Prev. \\
\hline Classical & 0.97 & $1^{*}$ & 0.4 & $1^{*}$ & 0.60 & 0.89 & $1^{*}$ & 0.93 & $1^{*}$ & 0.125 \\
\hline ML & 0.96 & 0.72 & 1 & 1 & 0.85 & 0.89 & 0.70 & 1 & 1 & 0.2 \\
\hline MCMC & 0.96 & 0.72 & 0.99 & 0.99 & 0.85 & 0.88 & 0.69 & 0.99 & 0.99 & 0.2 \\
\hline
\end{tabular}

Polymerase chain reaction (PCR) for the detection of Haplosporidium nelsoni was evaluated using histology as a gold standard reference, which identified a lack of specificity of PCR (0.7) (Fegan 2000). Such an evaluation could be performed again using latent models to assess if histology is actually lacking in sensitivity or if false positives by PCR really exist. These latter could result, for example, from contamination of oysters by ingestion of the parasite. This scenario may illustrate the frequent 'What is that band?' question.

The agreement of values of sensitivity and specificity (see Table 8) between latent models shows that these methods are robust.

It is not easy to decide which is the best estimation of sensitivity and specificity for both diagnostic methods among the latent models. However, some assumptions may appear a little artificial. Although results for maximum likelihood (ML) models are not significant, results obtained for infected oysters by means of the 2 diagnostic methods should be correlated, because efficiency of the techniques depends equally on the level of infection of the oysters (number of parasites per oyster), the stage of infection, and the quality of the tissue fixation. A consequence is that such techniques should not be used in combination, because results could be deceiving compared to independent ones since the correlation reduces the sensitivity of parallel testing and specificity of serial testing (Gardner et al. 2000). This is a very important point when developing a methodological process for diagnostic procedures.

Another assumption of the ML models, as well as of the first Bayesian models, is that sensitivity and specificity are independent of prevalence. In the case of Marteilia refringens in oysters, this assumption should be accepted only with great care. As a matter of fact, the level of infestation of oysters and the developmental stage of the parasite would have a direct effect on the value of sensitivity. Other studies have shown major variations in the level of infestation, developmental stage of the parasite and prevalence throughout the year, marking a strong seasonality of the disease (Audemard et al. 2001). This effect is also shown in Tables $7 \& 8$ as underlined by the increasing trend of sensitivity with prevalence. This is clearly a limit of our study, as these variations were not considered, or adjusted. However, the difference is not significant for in situ hybridisation and is only significant for histology in Bayesian models (Table 7). Because of this, some of the uncertainty on real values of sensitivity and specificity is not diminished. Fortunately, this case is not rare and methodological approaches exist which deal with uncertainty in diagnostic testing for decision analysis (Smith \& Slenning 2000).

The sensitivity values are 0.96 and 0.72 for in situ hybridisation and histology respectively, and specificity values around 0.995 for both, as shown in Table 7 . The last MCMC model is the only model which allows no assumption of dependence between tests and level of prevalence. The higher sensitivity of in situ hybridisation compared to histology is encouraging for routine use of this diagnosis tool. For example, controlling importation in a free area, or detecting emergence of Marteilia refringens on suspicious cases, such as abnormal mortality of oysters, could be successfully achieved using this technique. Although the specificity appears high, extrapolation to other situations is difficult, especially if the preparation of samples is not perfectly controlled.

Results between ML and Bayesian methods are equivalent. Differences can be observed between the latent models and classical estimation of sensitivity and specificity for in situ hybridisation and histology. Performances of histology are overestimated and, in parallel, those of in situ hybridisation are underestimated by the classical statistical approaches. This is particularly significant in the case of high prevalence rates.

Several guidelines and recommendations exist for test validation studies in the medical literature (Jasehke et al. 1994), in veterinary literature (Jacobson 1998, Greiner \& Gardner 2000), and especially for DNA-based molecular diagnostic techniques for aquatic animal pathogens (Walker \& Subasinghe 2000).

A step of validation which is probably a source of uncertainty is the reproducibility in reading histological slides. It would be expected that histology has a lesser level of reproducibility than in situ hybridisation. However, our study does not provide strong support for this assumption.

Although the validation process for in situ hybridisation and histology as diagnostic methods for Marteilia refringens is not fully accomplished, this study provides indications of how to calculate some expected results of monitoring programmes such as predictive values, apparent and real prevalence, needs for sampling. 
Acknowledgements. This study was partly carried out with support from the European Commission and the Community Reference Laboratory for Mollusc Diseases. Authors also wish to acknowledge help received from Dr. O. Haenen and her colleagues at the Central Institute for Animal Disease Control, Lelystad, The Netherlands.

\section{LITERATURE CITED}

Audemard C, Barnaud A, Collins CM, Le Roux F, Sauriau PG, Coustau C, Blachier P, Berthe FCJ (2001) Claire ponds as an experimental model for Marteilia refringens life-cycle studies: new perspectives. J Exp Mar Biol Ecol 257:87-108

Audemard C, Le Roux F, Barnaud A, Collins CM and 6 others (2002) Needle in a haystack: involvement of the copepod Paracartia grani in the life cycle of the oyster pathogen Marteilia refringens. Parasitology 124:315-323

Berthe FCJ, Pernas M, Zerabib M, Haffner P, Thébault A, Figueras AJ (1998) Experimental transmission of Marteilia refringens with special considerations for its life cycle. Dis Aquat Org 34:135-144

Berthe FCJ, Burreson EM, Hine M (1999) Use of molecular tools for mollusc disease diagnosis. Bull Eur Assoc Fish Path 19(6):277-278

Berthe FCJ (2000) Development and validation of DNA-based diagnostic techniques with particular reference to bivalve mollusc pathogens. In: Walker $\mathrm{P}$, Subasinghe RP (eds) DNA-based molecular diagnostic techniques. Research needs for standardization and validation of the detection of aquatic animal pathogens and diseases. FAO Fish Tech Pap 395:64-70

Berthe FCJ, Le Roux F, Peyretaillade E, Peyret P, Rodriguez D, Gouy M, Vivarès CP (2000) The existence of the phylum Paramyxea Desportes and Perkins, 1990 is validated by the phylogenetic analysis of the Marteilia refringens small subunit ribosomal RNA. J Eukaryot Microbiol 47(3):288-293

Brooks SP, Gelman A (1998) Alternative methods for monitoring convergence of iterative simulations. J Comput Graph Stat 7:434-455

Chriel M, Willeberg P (1997) Dependency between sensitivity, specificity and prevalence analysed by means of gibbs sampling. Epidemiol Santé Anim 2(12):31-32

Cochennec N, Le Roux F, Berthe F, Gérard A (2000) Detection of Bonamia ostreae based on small subunit ribosomal probe. J Invertebr Pathol 76:26-32

Comps M, Pichot Y, Papayianni P (1982) Recherche sur Marteilia maurini n. sp. parasite de la moule Mytilus galloprovincialis Lmk. Rev Trav Inst Pêches Marit 45:211-214

Enoe C, Georgiadis MP, Johnson WO (2000) Estimation of the sensitivity and specificity of diagnostic tests and disease prevalence when true disease state is unknown. Prev Vet Med 45:587-599

Fegan DF (2000) Evaluation of diagnostic tests: the epidemiological approach. In: Walker P, Subasinghe RP (eds) DNAbased molecular diagnostic techniques. Research needs for standardization and validation of the detection of aquatic animal pathogens and diseases. FAO Fish Tech Pap 395:30-37

Gardner IA, Stryhn H, Lind P, Collins MT (2000) Conditional dependence between tests affects the diagnosis and surveillance of animal diseases. Prev Vet Med 45:107-122.

Greiner M, Gardner IA (2000) Epidemiological issues in the validation of veterinary diagnostic tests. Prev Vet Med 45: $3-22$

Grizel H (1985) Etude des récentes épizooties de l'huître plate
(Ostrea edulis Linné) et leur impact sur l'ostréiculture bretonne. PhD thesis, Université des Sciences et Techniques du Languedoc, Montpellier

Grizel H, Comps M, Bonami JR, Cousserans F, Duthoit JL, Le Pennec MA (1974) Recherche sur l'agent de la maladie de la glande digestive de Ostrea edulis Linne. Bull Inst Pêches Marit 240:7-29

Hui SL, Walter SD (1980) Estimating the error rates of diagnostic tests. Biometrics 36:167-171

Jacobson RH (1998) Validation of serological assays for diagnosis of infectious diseases. Rev Sci Tech OIE 17:469-486

Jaeschke R, Guyatt G, Sackett DL (1994) Users guides to the medical literature. 3. How to use an article about a diagnostic test. Are the results of the study valid? J Am Med Assoc 271:389-391

Joseph L, Gyorkos TW, Coupal L (1995) Bayesian estimation of disease prevalence and the parameters of the diagnostic test in the absence of a gold standard. Am J Epidemiol 141:263-272

Kleeman SN, Le Roux F, Berthe F, Adlard RD (2002) Specificity of PCR and in situ hybridisation assays designed for detection of Marteilia sydneyi and $M$. refringens. Parasitology 125:131-141

Le Roux F, Audemard C, Barnaud A, Berthe F (1999) DNA probes as potential tools for detection of Marteilia refringens. Mar Biotechnol 1(6):588-597

Le Roux F, Lorenzo G, Peyret P, Audemard C, Figueras A, Vivarès G, Gouy M, Berthe FCJ (2001) Molecular evidence for the existence of two species of Marteilia refringens in Europe. J Eukaryot Microbiol 48(4):449-454

Longshaw M, Feist SW, Matthews A, Figueras A (2001) Ultrastructural characterisation of Marteilia species (Paramyxea) from Ostrea edulis, Mytilus edulis and Mytilus galloprovincialis in Europe. Dis Aquat Org 44:137-142

OIE (Office International des Epizooties) (2003a) Aquatic animal health code, 7 th edn. OIE, Paris

OIE (Office International des Epizooties) (2003b) Manual of diagnostic tests for aquatic animals, 4 th edn. OIE, Paris

Perkins FO, Wolf PH (1976) Fine structure of Marteilia sydneyi sp. n.-Haplosporidan pathogen of Australian oysters. J Parasitol 62(4):528-538

Pouillot R, Gerbier G (2000) A bayesian method for the evaluation of the sensitivity and specificity of correlated diagnostic tests in the absence of gold standards. Proc 9th International Society for Veterinary Epidemiology and Ecology (ISVEE) symposium, Aug 6-11, Brechenridge, CO. ISVEE, $p$ 969-972

Pouillot R, Gerbier G, Gardner IA (2002) 'TAGS', a program for the evaluation of test accuracy in the absence of a gold standard. Prev Vet Med 53:67-81

Robert R, Borel M, Pichot Y, Trut G (1991) Growth and mortality of the European flat oyster Ostrea edulis in the Bay of Arcachon (France). Aquat Living Resour 4:265-274

Smith RD, Slenning BD (2000) Decision analysis: dealing with uncertainty in diagnostic testing. Prev Vet Med 45: 139-162

Spiegelhalter D, Thomas A, Best N, Gilks W (1996) BUGS 0.5: Bayesian Inference using Gibbs Sampling-Manual (Version ii). Med Research Council Biostatistics Unit, Cambridge

Stokes NA, Burreson EM (1995) A sensitive and specific DNA probe for the oyster pathogen Haplosporidium nelsoni. J Eukaryot Microbiol 42:350-357

Thébault A, Berthe F, Audigé L (2001) Certifying the French population of Crassostrea gigas free from exotic diseases: a risk analysis approach. In: Rodgers CJ (ed) Risk analysis in aquatic animal health: Proceedings of the OIE International Conference, Paris, 8-10 February 2000. Office 
International des Epizootes, Paris, p 62-69

Tigé G, Rabouin MA (1976) Etude d'un lot de moules transférées dans un centre touché par l'épizootie affectant l'huître plate. ICES CM K/21:1-10

Villalba A, Mourelle SG, López MC, Carballal MJ, Azevedo C (1993) Marteiliasis effecting cultured mussels Mytilus galloprovincialis of Galicia (NW Spain). I. Etiology, phases of the infection, and temporal and spatial variability in

Editorial responsibility: Albert Sparks,

Seattle, Washington, USA prevalence. Dis Aquat Org 16:61-72

Walker P, Subasinghe RP (2000) DNA-based Molecular Diagnostic Techniques. Research needs for standardization and validation of the detection of aquatic animal pathogens and diseases. FAO Fish Tech Pap 395, p 93

Zrncic S, Le Roux F, Oraic D, Sostaric B, Berthe FCJ (2001) First record of Marteilia sp in mussels Mytilus galloprovincialis in Croatia. Dis Aquat Org 44:143-148

Submitted: August 9, 2003; Accepted: November 15, 2004

Proofs received from author: April 1, 2005 